\title{
PHYSIOLOGICAL RESPONSES OF TWO TROPICAL WEEDS TO SHADE. II. LEAF GAS EXCHANGE AND NITROGEN CONTENT ${ }^{1}$
}

\author{
MOACYR BERNARDINO DIAS-FILHO²
}

\begin{abstract}
Ipomoea asarifolia (Desr.) Roem. \& Schultz (Convolvulaceae) and Stachytarpheta cayennensis (Rich) Vahl. (Verbenaceae), two weeds found in pastures and crop areas in the Brazilian Amazonia, Brazil, were grown in controlled environment cabinets under high $\left(800-1000 \mu \mathrm{mol} \mathrm{m} \mathrm{m}^{-2} \mathrm{~s}^{-1}\right)$ and low (200-350 $\left.\mu \mathrm{mol} \mathrm{m}^{-2} \mathrm{~s}^{-1}\right)$ light regimes during a 40-day period. The objective was to determine the effect of shade on photosynthetic features and leaf nitrogen content of $I$. asarifolia and $S$. cayennensis. High-irradiance grown I. asarifolia leaves had significantly higher dark respiration and light saturated rates of photosynthesis than low-irradiance leaves. No significant differences for these traits, between treatments, were observed in S. cayennensis. Low-irradiance leaves of both species displayed higher $\mathrm{CO}_{2}$ assimilation rates under low irradiance. High-irradiance grown leaves of both species had less nitrogen per unit of weight. Low-irradiance $S$. cayennensis had more nitrogen per unit of leaf area than high-irradiance plants; however, I. asarifolia showed no consistent pattern for this variable through time. For $S$. cayennensis, leaf nitrogen content and $\mathrm{CO}_{2}$ assimilation were inversely correlated to the amount of biomass allocated to developing reproductive structures. These results are discussed in relation to their ecological and weed management implications.
\end{abstract}

Index terms: photosynthesis, leaf nitrogen, Amazonia, Ipomoea asarifolia, Stachytarpheta cayennensis.

\section{RESPOSTAS FISIOLÓGICAS DE DUAS PLANTAS INVASORAS TROPICAIS AO SOMBREAMENTO II. TROCA GASOSA E CONTEÚDO DE NITROGÊNIO FOLIAR}

\begin{abstract}
RESUMO - Ipomoea asarifolia (Desr.) Roem. \& Schultz (Convolvulaceae) e Stachytarpheta cayennensis (Rich) Vahl. (Verbenaceae), duas plantas invasoras encontradas em pastagens e áreas agrícolas da Amazônia brasileira, foram cultivadas durante 40 dias, em câmaras de crescimento sob alto (800-1000 $\left.\mu \mathrm{mol} \mathrm{m}^{-2} \mathrm{~s}^{-1}\right)$ e baixo $\left(200-350 \mu \mathrm{mol} \mathrm{m}^{-2} \mathrm{~s}^{-1}\right)$ regime de luz. O objetivo foi estudar o efeito do sombreamento nas características fotossintéticas e no teor de nitrogênio de I. asarifolia e $S$. cayennensis. As folhas de I. asarifolia cultivadas sob regime de luz alta apresentaram valores de respiração no escuro e taxa máxima de fotossíntese significativamente maiores que das folhas cultivadas sob baixa luz. Em S. cayennensis, não houve diferença significativa, entre tratamentos, quanto a esses parâmetros. Em ambas espécies, folhas desenvolvidas sob baixa irradiância apresentaram maiores taxas de assimilação de $\mathrm{CO}_{2}$ sob baixos níveis de irradiância. Em ambas as espécies, plantas cultivadas em luz alta apresentaram menores teores de nitrogênio por unidade de peso foliar. Em $S$. cayennensis, folhas de baixa irradiância tiveram maior teor de $\mathrm{N}$ por unidade de área que em folhas de plantas de luz alta; no entanto, em I. asarifolia não foi observado um padrão definido quanto a essa variável durante o período experimental. O conteúdo de $\mathrm{N}$ foliar e a assimilação de $\mathrm{CO}_{2} \mathrm{em}$ S. cayennensis foram inversamente correlacionados com o percentual de biomassa alocado para estruturas reprodutivas. Esses resultados são discutidos com relação a suas importâncias ecológica e de manejo.
\end{abstract}

Termos para indexação: fotossíntese, nitrogênio foliar, Amazônia, Ipomoea asarifolia, Stachytarpheta cayennensis.

\footnotetext{
${ }^{1}$ Accepted for publication on August 28, 1998.

2 Agronomist, Ph.D., Embrapa-Centro de Pesquisa Agroflorestal da Amazônia Oriental, Caixa Postal 48, CEP 66017-970 Belém, PA, Brazil. E-mail: moacyr@ufpa.br
}

\section{INTRODUCTION}

In agricultural ecosystems the light environment can be extremely variable and in many instances, 
may determine the composition of the weedy flora of the area. This is particularly true for tropical pastures, where selective grazing may create zones with relatively dense or sparse plant cover consequently creating contrasting light environments over relatively small areas. In these environments, weed seedlings may have to start their development under conditions of permanent shade or, during their development, be shaded by the fast growing tropical grasses or pasture weeds. Information on the physiological responses of weedy species to distinct light conditions can be critical in determining their occurrence potential and in helping to understand their competitive ability under different management situations so as to devise more effective control strategies. Managing tropical pasture weeds through an improved understanding of their ecophysiology is particularly important for areas like Brazilian Amazonia, where ecologically sound weed management strategies could decrease further deforestation by helping to increase the agricultural sustainability of already deforested areas.

Ipomoea asarifolia (Desr.) Roem. \& Schultz and Stachytarpheta cayennensis (L.C. Rich) Vahl are important weedy species of pasture and agricultural areas in Brazilian Amazonia (Dias-Filho, 1990). Stachytarpheta cayennensis is also considered a noxious weed in other regions of Brazil (Lorenzi, 1991) and throughout the tropics (Nair et al., 1982; Haselwood \& Motter, 1983; Kleinschmidt \& Johnson, 1987), and many species of the genus Ipomoea are noxious invaders of agricultural areas (Elmore et al., 1990). The occurrence pattern of these species in the field suggests that light, among other resources, might be an important determinant of their success.

Because photosynthesis and stomatal behavior are associated with dry matter accumulation, and because light is known to limit carbon accumulation, and nitrogen content understanding these processes in weeds may provide insight as to their effects on crop growth, help predict their occurrence, and ultimately provide the needed information for their management.

A previous work determined the sun-shade acclimation characteristics of $I$. asarifolia and S. cayennensis by measuring their growth and bio- mass allocation patterns in response to high and low irradiance conditions (Dias-Filho, 1999). The objective of this study was to determine photosynthetic features, stomatal conductance and leaf nitrogen content of I. asarifolia and S. cayennensis developed at contrasting irradiance environments.

\section{MATERIAL AND METHODS}

\section{Plant material and growing conditions}

Details on plant material and growing conditions were previously described (Dias-Filho, 1999). Briefly, Ipomoea asarifolia (Convolvulaceae) and Stachytarpheta cayennensis (Verbenaceae) were initially cultivated in $15 \mathrm{~cm}$ plastic pots in a greenhouse. Following expansion of the first two true leaves (about 21 days after germination), plants were transferred from the greenhouse to two Conviron growth chambers (Model PGW36. Controlled Environments, Inc. Pembina, ND) set at $28 / 24^{\circ} \mathrm{C}$ day/night air temperatures, $70 \%$ relative humidity, and $12-\mathrm{h}$ photoperiod.

Within each growth chamber, a high- and a low-irradiance environment were simulated by placing multiple layers of neutral density shade cloth beneath the light source of half of each growth chamber. Light, monitored throughout the experiment with a light meter (Model LI-1905 light meter, Li-Cor, Inc. Lincoln, NE) at canopy height, ranged between 800 and $1000 \mu \mathrm{mol} \mathrm{m}^{-2} \mathrm{~s}^{-1}$ for high-irradiance and between 200 and $350 \mu \mathrm{mol} \mathrm{m}^{-2} \mathrm{~s}^{-1}$ for low-irradiance treatments.

All pots were watered daily to full capacity with deionized water and fertilized every five days with $50 \mathrm{~mL}$ per pot of a water soluble fertilizer solution $(15: 30: 15$; $\left.\mathrm{N}: \mathrm{P}_{2} \mathrm{O}_{5}: \mathrm{K}_{2} \mathrm{O} ; 3.5 \mathrm{~g} \mathrm{~L}^{-1}\right)$.

\section{Gas exchange}

Gas exchange parameters were measured on plants just before the fifth harvest, i.e., when the plants had been in the growth chamber for 40 days. A photosynthesis $(A)$ versus irradiance (PFD) response curve (starting at ca. $1400 \mu \mathrm{mol} \mathrm{m} \mathrm{m}^{-2} \mathrm{~s}^{-1}$ and decreasing in five steps to 0 ), was measured in the laboratory on the most recent, fully expanded intact leaf of all plants using a portable photosynthesis system (Model LI-6200, LI-COR, Inc., Lincoln, $\mathrm{NE}$ ). Gas exchange parameters were calculated on a leaf area basis. The amount of leaf area in the chamber (cuvette) was approximately $2.2 \times 10^{-3} \mathrm{~m}^{2}$ for I. asarifolia and $1.5 \times 10^{-3} \mathrm{~m}^{2}$ for $S$. cayennensis. The light levels were obtained by combining neutral-density filters between the leaf chamber and the light source, a high-pressure sodium 
vapor lamp $(1000 \mathrm{~W})$. Gas exchange measurements were made after an adjustment period of about $20 \mathrm{~min}$ to each new irradiance level. To absorb long-wave radiation and maintain constant leaf temperatures in the cuvette, a $10 \mathrm{~cm}$ deep Plexiglas circulating bath of cool water was suspended between the light source and the leaf cuvette For $S$. cayennensis, leaf temperature during gas exchange measurements was maintained at $25.2 \pm 0.9^{\circ} \mathrm{C}$ (low-irradiance plants, mean \pm s.d.) and $25.5 \pm 0.8^{\circ} \mathrm{C}$ (high-irradiance plants), except when it was necessary to measure gas exchange in the dark, which resulted in mean leaf temperature of $23.3 \pm 0.8^{\circ} \mathrm{C}$ (low-irradiance) or $23.3 \pm 0.7^{\circ} \mathrm{C}$ (high-irradiance). For I. asarifolia, leaf temperatures were $26.7 \pm 0.7^{\circ} \mathrm{C}$ (low-irradiance) or $26.7 \pm 0.8^{\circ} \mathrm{C}$ (high-irradiance); leaf temperatures in the dark were $23.3 \pm 0.2^{\circ} \mathrm{C}$ (low-irradiance) and $23.3 \pm 0.1{ }^{\circ} \mathrm{C}$ (high-irradiance). After exposure to the lowest PFD, the plants were left for 30 min in the dark and measurements were made to obtain dark respiration $\left(R_{d}\right)$ values. Five replicate plants of each species per experiment and one leaf per plant were sampled. The leaf-to-air vapor pressure gradient inside the cuvette during all measurements was 9-12 $\mathrm{mmol} \mathrm{mol}^{-1}$.

Photosynthesis vs. irradiance response data provided direct estimates of highest measured value of photosynthetic rate $\left(A_{\max }\right)$. Apparent quantum yield of $\mathrm{CO}_{2}$ to incident irradiance $(\alpha)$ was calculated according to Thompson et al. (1992): the slope of a regression of five $R_{d}$ measurements and five low irradiance (ca. $200 \mu \mathrm{mol} \mathrm{m}^{-2} \mathrm{~s}^{-1}$ ) measurements of $\mathrm{CO}_{2}$ exchange, for each species and irradiance regime combination. The light compensation point was calculated as the ratio, $R_{d} / \alpha$

\section{Leaf nitrogen analysis}

Leaf nitrogen was measured on each individual leaf used for the gas exchange measurements, and also on all leaves of each individual plant at each harvest date and light treatment combination. In all cases, leaf nitrogen content was measured with a nitrogen analyzer (Model NA 1500, series 2. Carlo Erba Strumentazione, Milan, Italy). The instrument was calibrated with both an NBS "citrus leaf" and organic standard. Precision was $\pm 0.17 \%$ of $\mathrm{N}$.

\section{Experimental design and statistical analysis}

The experiment was arranged in a randomized complete block design with five replications. All pots were rotated within replications (blocks) every day to minimize variation in growth due to possible temperature and irradiance differences within the growth chamber.
Differences in net photosynthesis and stomatal conductance response curves for species and irradiance regime treatments were analyzed by analysis of variance with repeated measures (Von Ende, 1993). The betweensubject main effects were species and irradiance regimes, and the within-subjects or repeated measures effect was irradiance level. Homoscedastic residuals were obtained with logarithmically transformed values for photosynthesis and stomatal conductance. No severe departures from the normality assumption were detected by examining halfnormal probability plots of z-transformed within-cell correlations for both data sets. Compound symmetry of the covariance matrix of each analysis was tested by the Mauchly's sphericity test. The Huynh-Feldt (Von Ende, 1993) correction was considered for both analyses. Post hoc contrasts comparing species and irradiance regime differences in photosynthesis and stomatal conductance, within each irradiance level, were calculated.

\section{RESULTS AND DISCUSSION}

There were significant species and species $\times$ irradiance regime main effect differences in $\mathrm{CO}_{2}$ assimilation rates; no significant difference could be detected for the irradiance regime main effect. Among the within-subjects main effects only irradiance level and its interactive effect with the irradiance regimes were statistically significant. For both species, low-irradiance-grown plants had a tendency to display higher assimilation values under the lowest irradiance levels (Fig. 1). Post hoc contrasts indicated that in I. asarifolia significant differences in the light response curve between irradiance environments were observed at the first (ca. $1400 \mu \mathrm{mol} \mathrm{m}^{-2} \mathrm{~s}^{-1}, \mathrm{~F}_{1.16}=5.4, \mathrm{P}=0.03$ ), second (ca. $900 \mu \mathrm{mol} \mathrm{m} \mathrm{m}^{-2} \mathrm{~s}^{-1}, \mathrm{~F}_{1.16}=5.4, \mathrm{P}=0.03$ ) and fifth (ca. $200 \mu \mathrm{mol} \mathrm{m}{ }^{-2} \mathrm{~s}^{-1}, \mathrm{~F}_{1.16}=19.5, \mathrm{P}<0.001$ ) irradiance levels. High-irradiance grown $I$. asarifolia leaves had higher $\mathrm{CO}_{2}$ assimilation rates at the two highest irradiance levels (i.e., ca. 1400 and $\left.900 \mu \mathrm{mol} \mathrm{m}^{-2} \mathrm{~s}^{-1}\right)$, but lower assimilation at the lowest irradiance level (i.e., ca. $200 \mu \mathrm{mol} \mathrm{m} \mathrm{m}^{-2} \mathrm{~s}^{-1}$ ). For $S$. cayennensis, significant differences in $\mathrm{CO}_{2}$ assimilation rates between irradiance regimes could be detected only at the fifth (ca. $200 \mu \mathrm{mol} \mathrm{m} \mathrm{m}^{-2} \mathrm{~s}^{-1}$, $\left.\mathrm{F}_{1.16}=23.03, \mathrm{P}<0.0001\right)$ irradiance level with higher $\mathrm{CO}_{2}$ assimilation for low-irradiance grown plants. Post hoc contrasts on differences between species, 
within each light regime, showed that under the high irradiance regime the two species differed in $\mathrm{CO}_{2}$ assimilation only at the fourth (ca. $450 \mu \mathrm{mol} \mathrm{m}^{-2} \mathrm{~s}^{-1}, \mathrm{~F}_{1.16}=4.5, \mathrm{P}=0.048$ ) and the fifth (ca. $200 \mu \mathrm{mol} \mathrm{m}{ }^{-2} \mathrm{~s}^{-1}, \mathrm{~F}_{1.16}=7.6, \mathrm{P}=0.013$ ) irradiance levels, with higher rates for S. cayennensis. Comparison of low-irradiance grown plants revealed higher assimilation rates for S. cayennensis at all irradiance levels $\left(\mathrm{F}_{1.16} \geq 7.09\right.$, $\mathrm{P} \leq$ 0.017) (Fig. 1).

Leaf stomatal conductance, $g$, in $S$. cayennensis behaved differently from that of I. asarifolia; it was sensitive to growing conditions and was significantly reduced by growth at high photon flux density (Fig. 2). Comparisons between irradiance regimes assessed by post hoc contrasts showed significant differences in $g$ for $S$. cayennensis at the first (ca. $1400 \mu \mathrm{mol} \mathrm{m}^{-2} \mathrm{~s}^{-1}, \mathrm{~F}_{1.16}=7.9, \mathrm{P}=0.01$ ) and fifth
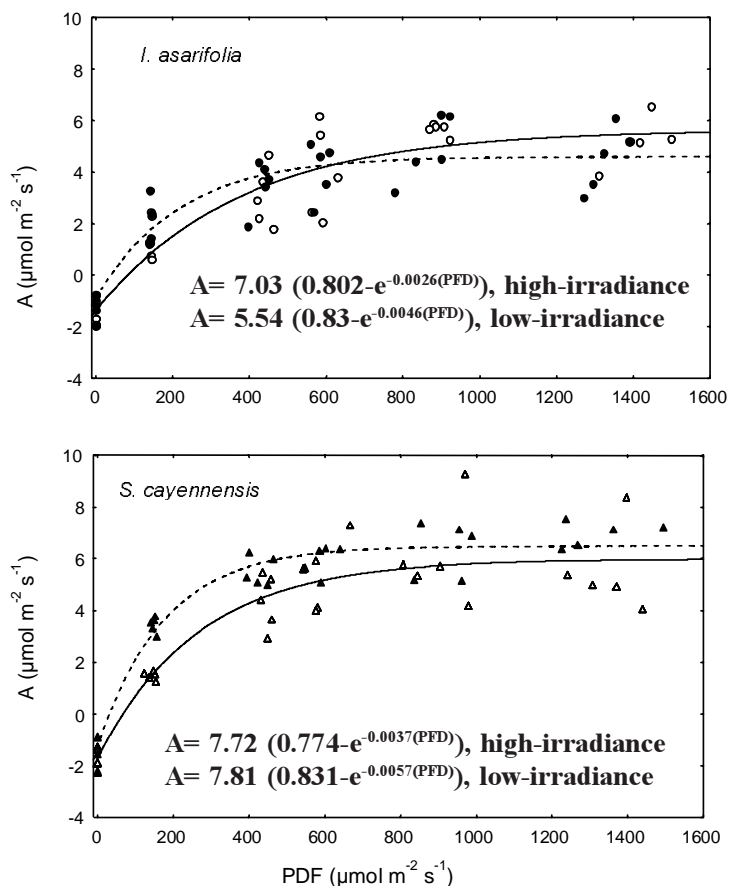

FIG. 1. Light (PFD) response curves of photosynthesis (A) of $I$. asarifolia and $S$. cayennensis grown under high- (open symbols and solid lines) and low-irradiance (closed symbols and dashed lines) conditions. (ca. $200 \mu \mathrm{mol} \mathrm{m}^{-2} \mathrm{~s}^{-1}, \mathrm{~F}_{116}=11.1, \mathrm{P}=0.004$ ) irradiance levels, and in the dark $\left(\mathrm{F}_{1.16}=4.6, \mathrm{P}=0.04\right)$; low-irradiance $S$. cayennensis leaves had higher $g$ in these irradiance levels, but lower $g$ in the dark (Fig. 2). No significant differences in $g$ between irradiance regimes could be detected for I. asarifolia.

Light-saturated photosynthesis ( $\mathrm{A}_{\max }$, Table 1 , Fig. 1) within each species was higher for plants subjected to the high-irradiance treatment. Between species, $\mathrm{A}_{\max }$ was higher for $S$. cayennensis, under both irradiance regimes. Within species differences in $\mathrm{R}_{d}$, assessed by post hoc contrasts of the light response curves, revealed that high-irradiance grown I. asarifolia leaves displayed higher (more negative) $\mathrm{R}_{d}$ than low-irradiance leaves $\left(\mathrm{F}_{1.16}=8.9, \mathrm{P}=0.008\right)$. No other statistically significant difference in $\mathrm{R}_{d}$ within and between species and treatments could be
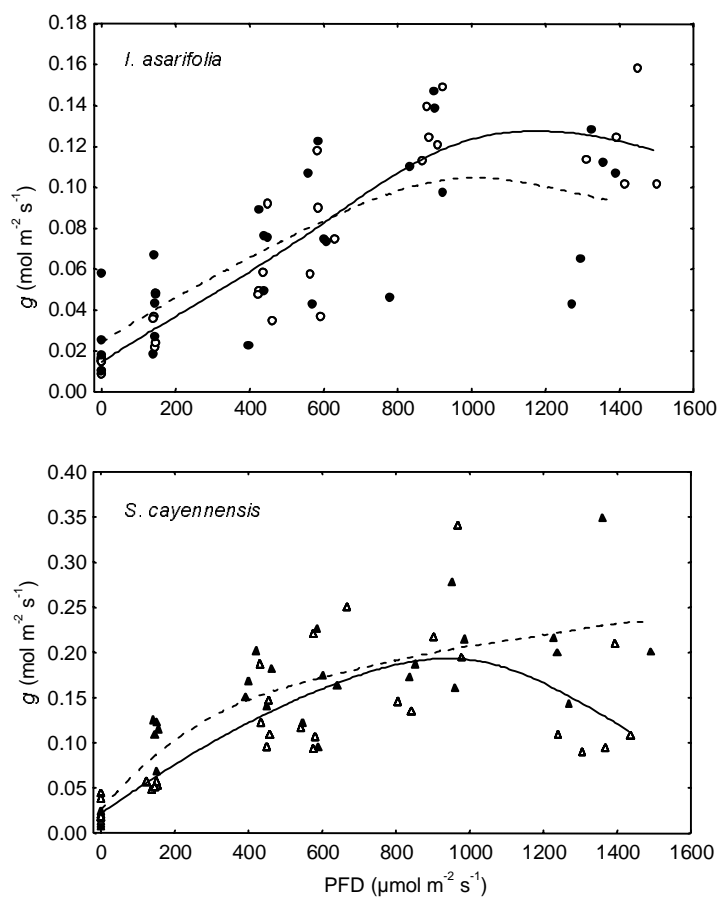

FIG. 2. Light (PFD) response curves of stomatal conductance $(g)$ of $I$. asarifolia and $S$. cayennensis grown under low- (closed symbols and dashed lines) and high-irradiance (open symbols and solid lines) conditions. Curves fitted by distance-weighted least squares. 
detected. However, a tendency for higher $\mathrm{R}_{d}$ values for high-irradiance grown plants from both species and for $S$. cayennensis compared to I. asarifolia, can be observed in Table 1.

The apparent quantum efficiency, $\alpha$, was sensitive to the light regime during growth (Table 1). Growth at the low-irradiance environment caused an average increase in $\alpha$ of $19 \%$ and $50 \%$, respectively in $I$. asarifolia and $S$. cayennensis relative to high-irradiance plants; this difference, however, was statistically significant only for $S$. cayennensis $(\mathrm{t}=7.67, \mathrm{P}<0.0001)$. If we consider the reciprocal of $\alpha$, the quantum requirement (quanta $\mathrm{CO}_{2}^{-1}$ ), as a measure of efficiency of photosynthesis, high-irradiance $S$. cayennensis was significantly $(\mathrm{t}=32.9$, $\mathrm{P}<0.0001)$ more efficient than low-irradiance plants (mean \pm s.d., $44.62 \pm 2.5$ vs. $31.27 \pm 2.6$ ), while no significant difference in photosynthetic efficiency could be detected between high- $(54.92 \pm 11.6)$ and low-irradiance $(43.58 \pm 7.3)$ I. asarifolia. Light compensation point, $\mathrm{R}_{d} / \alpha$, was also influenced by the irradiance regimes, being at least $45 \%$ higher in high-

TABLE 1. Photosynthetic parameters of Stachytarpheta cayennensis and Ipomoea asarifolia under high- and low-irradiance regimes. Symbols and units; $A_{\max }$ is light saturated photosynthesis rate

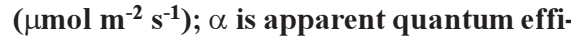
ciency (mol $\mathrm{CO}_{2}$ photon $\left.^{-1}\right) ; \mathbf{R}_{d}$ is dark respiration $\left(\mu \mathrm{mol} \mathrm{m}^{-2} \mathrm{~s}^{-1}\right)$ and $R_{d} / \alpha$ is light compensation point $\left(\mu \mathrm{mol} \mathrm{m} \mathrm{m}^{-2} \mathrm{~s}^{-1}\right)$. Values are means ( \pm s.d. $), \mathbf{n}=\mathbf{5}$.

\begin{tabular}{lll}
\hline Parameter & \multicolumn{1}{c}{ High-irradiance } & Low-irradiance \\
\hline \multicolumn{2}{c}{ Stachytarpheta cayennensis } \\
$\mathrm{A}_{\max }$ & 9.25 & 7.56 \\
$\alpha$ & $0.022(0.001)$ & $0.032(0.002)$ \\
$\mathrm{R}_{d}$ & $1.72(0.41)$ & $1.37(0.55)$ \\
$\mathrm{R}_{d} / \alpha$ & $76.50(16.7)$ & $42.21(15.1)$ \\
& \multicolumn{2}{c}{ Ipomoea asarifolia } \\
$\mathrm{A}_{\max }$ & $6.54 \quad 0.22$ \\
$\alpha$ & $0.019(0.005)$ & $0.023(0.004)$ \\
$\mathrm{R}_{d}$ & $1.52(0.53)$ & $1.24(0.44)$ \\
$\mathrm{R}_{d} / \alpha$ & $80.87(26.6)$ & $54.63(23.0)$ \\
\hline
\end{tabular}

irradiance grown I. asarifolia and S. cayennensis. As observed in Table 1, most of the difference in $\mathrm{R}_{d} / \alpha$ between species can be attributed to differences in $\alpha$. As a result of the higher $\alpha$ observed in $S$. cayennensis, $\mathrm{R}_{d} / \alpha$ in this species was lower than that in I. asarifolia (Table 1).

In both species, nitrogen content per unit leaf weight was higher for low-irradiance plants (Fig. 3). However, when expressed on a leaf area basis, nitrogen content in high-irradiance $S$. cayennensis was higher than in low-irradiance plants. For I. asarifolia, no systematic tendency was evident, as nitrogen content, on a leaf area basis, varied throughout time in an inconsistent pattern between irradiance regimes (Fig. 3). A positive correlation between nitrogen content on a weight basis and $\mathrm{CO}_{2}$ assimilation under the highest irradiance level (ca. $1400 \mu \mathrm{mol} \mathrm{m}{ }^{-2} \mathrm{~s}^{-1}$ ) was observed in high-irradiance $S$. cayennensis and I. asarifolia; in low-irradiance plants, a weaker correlation was found for $S$. cayennensis, but not for I. asarifolia, which displayed a stronger correlation between $\mathrm{CO}_{2}$ assimilation and leaf nitrogen at low irradiance (Table 2). Stomatal conductance, $g$, in S. cayennensis was positively and significantly correlated with leaf nitrogen content (Table 2), the slope of this relationship being steeper for low-irradiance plants. Thus, there was a stronger response of $g$ to leaf nitrogen on a mass basis in low-irradiance plants. I. asarifolia behaved differently from $S$. cayennensis, no relationship could be detected between $g$ and leaf nitrogen in high-irradiance plants, yet, a weak, but nonsignificant correlation between these attributes was also apparent in low-irradiance $I$. asarifolia (Table 2).

In $S$. cayennensis, the amount of biomass allocated to reproductive tissue (i.e., flowering bearing spikes) was negatively correlated to $\mathrm{CO}_{2}$ assimilation ( $\mathrm{r}=-0.53$ for high-irradiance and $\mathrm{r}=-0.33$, for low-irradiance plants), stomatal conductance $(\mathrm{r}=-0.74$ for high-irradiance and $\mathrm{r}=-0.33$, for low-irradiance plants) and also to the nitrogen content (on a mass basis) from the leaf used for the gas exchange measurements (the youngest fully expanded leaf) (Table 2). Yet, none of these relationships were statistically significant $(\mathrm{P}>0.05)$. However, when mean nitrogen content from all leaves of each individual plant was considered, as opposed to 
the leaf used for the gas exchange measurements, a strong and highly significant negative correlation was found between leaf nitrogen (on a mass basis) at the 30 - and 40-day evaluation periods (when most plants have started reproduction) versus the corresponding biomass allocated to flower bearing spikes
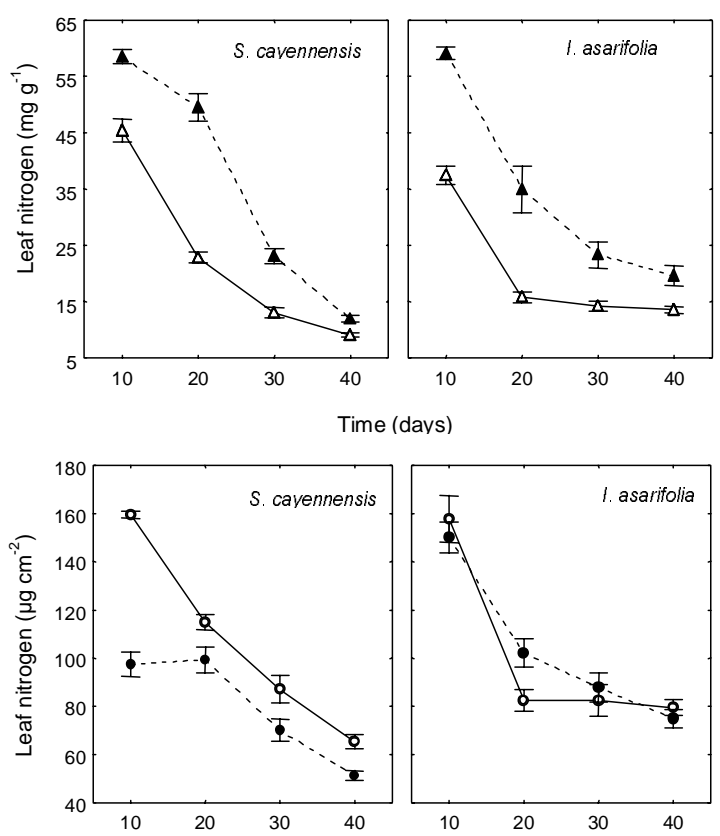

FIG. 3. Leaf nitrogen content (mean \pm s.e., $n=4)$ on an area $\left(\mu \mathrm{g} \mathrm{cm}^{-2}\right)$ and mass $\left(\mathrm{mg} \mathrm{g}^{-1}\right)$ basis for I. asarifolia and $S$. cayennensis under low(closed symbols and dashed lines) and high-irradiance (open symbols and solid lines) conditions. during those periods by low- $(\mathrm{r}=-0.98, \mathrm{P}<0.0001$, $\mathrm{n}=8)$ and high-irradiance $(\mathrm{r}=-0.79, \mathrm{P}=0.02, \mathrm{n}=8)$ S. cayennensis plants. When leaf nitrogen on an area basis was considered, a similar relationship was observed for low- $(\mathrm{r}=-0.86, \mathrm{P}=0.007)$ and high-irradiance $(r=-0.67, P=0.07)$ plants. Due to the nonlinear relation between mean leaf nitrogen from all leaves of each plant and the corresponding reproductive biomass of high- and low-irradiance plants, these correlations were measured by Spearman rank order correlation (Potvin \& Roff, 1993).

The shape of the light response curve observed for I. asarifolia and, to some extent, for $S$. cayennensis, grown under the contrasting light environments (Fig. 1), was similar to those observed by Ramos \& Grace (1990) and Riddoch et al. (1991b) for a group of tropical trees and by Regnier et al. (1988) for the weed Abutilon theophrasti, grown under high and low irradiance. Low-irradiance grown plants had higher assimilation rates under lower irradiance and lower assimilation under higher irradiance levels. However, in the present study, high-irradiance $S$. cayennensis leaves had a tendency to exhibit lower $\mathrm{CO}_{2}$ assimilation under the highest irradiance level, when compared to lowirradiance plants. This unexpected behavior of high irradiance $S$. cayennensis leaves may be related to the amount of biomass allocated to reproductive tissue by these plants, as a negative relationship between the amount of biomass allocated to flower bearing spikes and $\mathrm{CO}_{2}$ assimilation was suggested by our data. This, in turn, was probably associated with the developing reproductive structures acting as a "competitive sink" with leaves for nitrogen (and probably other resources), leading to the lower leaf

TABLE 2. Slope ( $(s)$, correlation coefficient $(r)$ and significance level $(*=<0.05, * *=<0.01)$ of the correlations between $\mathrm{CO}_{2}$ assimilation $(A)$, stomatal conductance $(g)$, or the amount of biomass allocated to reproductive tissue $(R)$ vs. leaf nitrogen content $\left(\mathrm{mg} \mathrm{g}^{-1}\right) . \mathrm{n}=4$.

\begin{tabular}{|c|c|c|c|c|c|c|c|c|}
\hline \multirow[t]{3}{*}{ Parameter } & \multicolumn{4}{|c|}{ S. cayennensis } & \multicolumn{4}{|c|}{ I. asarifolia } \\
\hline & \multicolumn{2}{|c|}{ High-irradiance } & \multicolumn{2}{|c|}{ Low-irradiance } & \multicolumn{2}{|c|}{ High-irradiance } & \multicolumn{2}{|c|}{ Low-irradiance } \\
\hline & $s$ & $r$ & $s$ & $r$ & $s$ & $r$ & $s$ & $r$ \\
\hline$A$ & 0.7481 & $0.93 *$ & 0.3229 & 0.57 & 0.083 & 0.42 & 0.3838 & 0.78 \\
\hline$g$ & 0.0223 & $0.95 *$ & 0.0423 & $0.99 * *$ & 0.0006 & 0.07 & 0.006 & 0.47 \\
\hline$R$ & -0.0796 & -0.51 & -0.0266 & -0.31 & --- & --- & --- & --- \\
\hline
\end{tabular}


nitrogen content in plants with a higher proportion of biomass allocated to reproduction, as also suggested by our data. It is possible that the low leaf nitrogen content of high-irradiance plants may have rendered these plants more susceptible to photoinhibition as observed for other tropical species (Seemann et al., 1987). Developing reproductive structures acting as a sink for nitrogen has also been suggested for tropical legumes (Humphreys, 1991) and for crop species (Sadras et al., 1993; Sklensky \& Davies, 1993).

The positive relationship between leaf $\mathrm{CO}_{2}$ assimilation or stomatal conductance and leaf nitrogen content per unit area observed for $S$. cayennensis and, to some extent in I. asarifolia (Table 2), was expected and has also been reported in other studies involving tropical trees (Ramos \& Grace, 1990; Riddoch et al., 1991b; Tuohy et al., 1991) and crops (Sinclair \& Horie, 1989). Interestingly, no relationship between leaf nitrogen and stomatal conductance could be detected in low-irradiance I. asarifolia (Table 2).

Analysis of the parameters calculated from the light response curves data (Table 1) shows that within species, statistically significant differences between light treatments in the initial slope of the photosynthetic light response curves can be observed only for $S$. cayennensis. Low-irradiance treated plants of this species displayed a 50\% higher quantum efficiency. Yet a tendency for higher quantum efficiency in low-irradiance I. asarifolia is also apparent (Table 1). Other studies have shown that light regime during growth does not normally alter apparent quantum efficiency in temperate (Björkman, 1981; Mahall \& Schlesinger, 1982) or tropical (Sims \& Pearcy, 1989; Ramos \& Grace, 1990; Riddoch et al., 1991b) species. However, a tendency for higher $\alpha$ values in low-irradiance plants is usually observed in these studies. The larger $\alpha$ value in low-irradiance $S$. cayennensis relative to high-irradiance plants can explain the rapid raise in assimilation rate with increasing light observed in this species at the low-irradiance treatment (Fig. 1). When compared to low-irradiance I. asarifolia, low-irradiance $S$. cayennensis was particularly more efficient at the lower irradiance levels (i.e., ca. 200 and $450 \mu \mathrm{mol} \mathrm{m} \mathrm{m}^{-2} \mathrm{~s}^{-1}$ ), displaying significantly higher
$\mathrm{CO}_{2}$ assimilation rates at these irradiance levels than high-irradiance plants (Fig. 1).

The observed tendency for lower $\mathrm{R}_{d}$ values in low-irradiance plants (Table 1) is a common response also reported for other tropical species under similar conditions (Ramos \& Grace, 1990; Riddoch et al., 1991b; Thompson et al., 1992), and may, in part, have contributed to the net photosynthetic advantage exhibited by shade grown plants at the lower irradiance levels (Fig. 1). Light compensation point, $\mathrm{R}_{d} / \alpha$ (Table 1 ), of both species followed the same trend observed in other studies involving tropical species, in which higher light during growth leads to higher values of $\mathrm{R}_{d} / \alpha$ (Ramos \& Grace, 1990; Thompson et al., 1992). The values of $\mathrm{R}_{d} / \alpha$ calculated for I. asarifolia and S. cayennensis agree with values reported by Riddoch et al. (1991a) for two "weeds of gaps" from Nigeria, and do not suggest differences between these species in relation to their shade tolerance. However, it has been suggested from work with tropical tree seedlings that shade tolerance may not necessarily depend on leaf characteristics such as light compensation point (Thompson et al., 1992).

An important finding of this study was that, irrespective of light environment during growth, leaf nitrogen content and $\mathrm{CO}_{2}$ assimilation were inversely related to the allocation of biomass to developing reproductive structures in $S$. cayennensis. Based on this, it could be speculated that this species might be more vulnerable to stresses like mowing or fire at the initial stages of flowering because of reduced vigor as expressed by lower carbon gains, which could, in turn, restrict resprouting ability. Under natural conditions this limitation could be further enhanced as plants in the field, unlike the ones in the present study, could experience more limiting edaphic conditions. Such information might also have important practical implications for planning the most appropriate time for the control of this species.

\section{CONCLUSIONS}

1. The overall effect of shade is more deleterious to $S$. cayennensis, which has its photosynthetic efficiency and reproductive capacity negatively affected by shade. 
2. Developing reproductive structures act as a sink for leaf nitrogen in S. cayennensis at both light and shade environments.

\section{ACKNOWLEDGEMENTS}

To Katia Rodrigues for assistance during the gas exchange measurements; Todd Dawson, Sana Gardescu, Peter Marks and one anonymous reviewer that provided valuable suggestions to improve this manuscript.

\section{REFERENCES}

BJÖRKMAN, O. Responses to different quantum flux densities. In: LANGE, O.L.; NOBEL, P.A.; OSMOND, C.B.; ZIEGLER, H. (Eds.). Encyclopedia of plant physiology: Physiological Plant Ecology. Berlin: Springer-Verlag, 1981. v.12A, p.57-107.

DIAS-FILHO, M.B. Physiological responses of two tropical weeds to shade. I. Growth and biomass allocation. Pesquisa Agropecuária Brasileira, Brasília, v.34, n.6, p.945-952, jun. 1999.

DIAS-FILHO, M.B. Plantas invasoras em pastagens cultivadas da Amazônia: estratégias de manejo e controle. Belém: Embrapa-CPATU, 1990. 103p. (Embrapa-CPATU. Documentos, 52)

ELMORE, C.D.; HURST, H.R.; AUSTIN, D.F. Biology and control of morningglories (Ipomoea spp.). Reviews in Weed Science, v.5, p.83-114, 1990.

HASELWOOD, E.L.; MOTTER, G.G. Handbook of Hawaiian weeds. 2.ed. Honolulu: Univ. of Hawaii Press, 1983. 491p.

HUMPHREYS, L.R. Tropical pasture utilisation. Cambridge: Cambridge Univ. Press, 1991. 206p.

KLEINSCHMIDT, H.E.; JOHNSON, R.W. Weeds of Queensland. Brisbane: Queensland Department of Primary Industries, 1987. 469p.

LORENZI, H. Plantas daninhas do Brasil: terrestres, aquáticas, parasitas, tóxicas e medicinais. 2.ed. Nova Odessa: Plantarum, 1991. 440p.

MAHALL, B.E.; SCHLESINGER, W.H. Effects of irradiance on growth, photosynthesis, and water use ef- ficiency of seedlings of the Chaparral shrub, Ceanothus megacarpus. Oecologia, v.54, p.291299, 1982

NAIR, N.C.; MOHANAN, C.N.; SREEKUMAR, P.V Stachytarpheta cayennensis (L.C. Rich) Schan. A new record for India with a key to Indian species. Journal of Bombay Natural History Society, v.79, p.230-232, 1982.

POTVIN, C.; ROFF, D.A. Distribution-free and robust statistical methods: viable alternatives to parametric statistics? Ecology, v.7, p.1617-1628, 1993

RAMOS, J.; GRACE, J. The effects of shade on gas exchange of seedlings of four tropical trees from Mexico. Functional Ecology, v.4, p.667-677, 1990.

REGNIER, E.E.; SALVICCI, M.E.; STOLLER, E.W Photosynthesis and growth responses to light in soybean (Glycine max) and three broadleaf weeds. Weed Science, v.36, p.487-496, 1988.

RIDDOCH, I.; GRACE, J.; FASEHUN, F.E.; RIDDOCH, B.; LAPIDO, D.O. Photosynthesis and successional status of seedlings in a tropical semi-deciduous rain forest in Nigeria. Journal of Ecology, v.79, p.491503, 1991a.

RIDDOCH, I.; LEHTO, T.; GRACE, J. Photosynthesis of tropical tree seedlings in relation to light and nutrient supply. New Phytologist, v.119, p.137-147, 1991b.

SADRAS, V.O.; HALL, A.J.; CONNOR, D.J. Light-associated nitrogen distribution profile in flowering canopies of sunflower (Helianthus annuus L.) altered during grain growth. Oecologia, v.95, p.488494, 1993

SEEMANN, J.R.; SHARKEY, T.D; WANG, J.; OSMOND, C.B. Environmental effects on photosynthesis, nitrogen-use efficiency, and metabolite pools in leaves of sun and shade plants. Plant Physiology, v.84, p.796-802, 1987.

SIMS, D.A.; PEARCY, R.W. Photosynthetic characteristic of a tropical forest understory herb Alocasia macrorrhiza and a related crop species, Colocasia esculenta grown in contrasting light environments. Oecologia, v.79, p.55-59, 1989.

SINCLAIR, T.R.; HORIE, T. Leaf nitrogen, photosynthesis and crop radiation use efficiency: a review Crop Science, v.29, p.90-98, 1989. 
SKLENSKY, D.E.; DAVIES, P.J. Whole plant senescence: reproduction and nutrient partitioning. Horticultural Reviews, v.15, p.335-366, 1993

THOMPSON, W.A.; HUANG, L.-K.; KRIEDEMANN, P.E. Photosynthetic response to light and nutrients in sun-tolerant and shade-tolerant rainforest trees. II. Leaf gas exchange and component processes of photosynthesis. Australian Journal of Plant Physiology, v.19, p.19-42, 1992
TUOHY, J.M.; PRIOR, J.A.B.; STEWART, G.R. Photosynthesis in relation to leaf nitrogen and phosphorus content in Zimbabwean trees. Oecologia, v.88, p.378-382, 1991.

VON ENDE, C.N. Repeated-measures analysis: growth and other time-dependent measures. In: SCHEINER, S.M.; GUREVITECH, J.G. (Eds.). Design and analysis of ecological experiments. New York: Chapman and Hall, 1993. p.113-137. 